\title{
As relações de poder na escola pública: um estudo de caso*
}

\section{Relations of power in public schools: a case study}

\section{Las relaciones de poder en la escuela pública: un estudio de caso}

\author{
Maria Custódia Jorge Rocha* \\ Amália Gonçalves Fernandes***
}

\begin{abstract}
Resumo: Neste artigo, apoiando-nos em alguns autores que perspectivam o poder como um elemento substantivo - poder instituído - e outros que o analisam como um verbo em ação - poder instituinte (ROCHA, 2007), destacando algumas das tipologias de poder patentes na investigação sociológica e organizacional sobre a escola, apresentamos dados empíricos e discursos organizacionais, propiciados pela realização de um estudo de caso de caráter qualitativo. Podemos dizer, então, que as relações de poder na escola tanto possibilitam o reforço das relações hierárquicas e assimétricas de poder que se verificam entre os atores organizacionais, como viabilizam a criação de novos "círculos de poder", que podem ser ativados pontualmente ou ser objeto de uma atualização mais ou menos generalizada. Esses poderão reforçar-se e apresentar-se aos atores/alunos, nosso principal alvo de estudo, como os mais legítimos, sobrepondose a todos os outros mas não os anulando. O objetivo essencial é o de apresentar a organização escolar como um contexto eminentemente complexo, sobretudo quando analisada à luz da multiplicidade e cumulatividade das relações de poder que nela emergem e se concretizam.
\end{abstract}

Palavras-chave: Poder. Dominação. Resistência.

\begin{abstract}
In this paper, based on a few authors who see power as a substantive element - instituted power - and others who consider it as an action verb - instituting power (ROCHA, 2007) -, highlighting some types of power relevant in sociological and organizational research on schools, we present empirical data and institutional discourses, enabled by a case study of qualitative nature. Thus, we can say that relations of power in schools both allow the strengthening of hierarchical and asymmetrical relations of power that exist between institutional players and enable the creation of new "circles

* Este trabalho é financiado por Fundos Nacionais por meio da FCT - Fundação para a Ciência e a Tecnologia no âmbito do projecto PEst-OE/CED/UI1661/2011 do CIEd (Portugal).

** Universidade do Minho. E-mail: <mcrocha@ie.uminho.pt>

*** Agrupamento de Escolas Ave. E-mail: <amaliagf@gmail.com>
\end{abstract}


of power" that can be promptly activated or can be object of a modernization process held in a more or less generalized manner. This may be reinforced and introduced to players/students, our main target of study, as the most legitimate object, superseding all others but not canceling them. The key objective is to present school organization as a highly complex environment, especially when considered in the light of the multiple and cumulative relations of power that emerge and are materialized.

Keywords: Power. Domination. Resistance.

Resumen: En el presente artículo, con el apoyo de algunos autores que perspectivam el poder como un elemento sustancial - poder establecido -, y otros que lo analizan como un verbo de acción - poder instituyente (ROCHA, 2007), destacando algunas de las tipologías de poder manifiestas en la investigación sociológica y organizacional acerca de la escuela, presentamos dados empíricos y discursos organizacionales, facultados por la realización de un estudio de caso de naturaleza cualitativa. Podemos decir, entonces, que las relaciones de poder en la escuela permiten tanto el reforzamiento de la jerarquía y asimetría del poder verificadas en los atores organizacionales, como hacen viable la constitución de nuevos "círculos de poder" que se puede activar puntualmente o ser objecto de uma actualización más o menos generalizadas. Los dichos círculos podrán reforzarse y presentarse a los alumnos/atores, el foco principal de nuestro estudio, como los más legítimos, por encima de todos pero no los anulando. El objectivo esencial es presentar la organización escolar como un contexto eminentemente complejo, sobre todo cuando analizada a la luz de la multiplicidad y la acumulación de las relaciones de poder que en ella surgen y se concretan.

Palabras clave: Poder. Dominación. Resistencia.

\section{Introdução}

Neste artigo, tendo em conta um estudo de caso de cariz qualitativo ${ }^{1}$, adotando uma focalização normativa, interpretativa e sobretudo descritiva, que nos é permitida pela revisão bibliográfica e análise de conteúdo de um conjunto de documentos e entrevistas semiestruturadas, damos conta de algumas dinâmicas organizacionais que nos permitem perceber as relações de poder que se verificam entre alunos e outros elementos da comunidade escolar/educativa, dentro de configurações e estruturas organizacionais escolares específicas e fora delas.

Mais do que um substantivo, o poder é por nós visto como um verbo em ação. Mais do que falar em poder, falamos em relações de poder, de sua

\footnotetext{
${ }^{1}$ Efetuado por Amália Fernandes (2011) no âmbito de um Mestrado em Educação - Administração Educacional, sob orientação de Maria Custódia Jorge Rocha, Prof. Auxiliar do Departamento de Ciências da Educação, Instituto de Educação - Universidade do Minho, Braga, Portugal.
} 
multiplicidade e cumulatividade. Desta feita, na organização escolar vigoram tanto poderes instituídos, por quem de direito, como poderes instituintes atualizados pelos atores organizacionais, neste caso sobretudo os alunos. Assim acontece num contexto específico de ação: a escola Lua-Sol, tal como a designamos no nosso estudo; é uma instituição pública do Ensino Básico - $2^{\circ}$ e $3^{\circ}$ Ciclos - Sede de um Agrupamento de Escolas. Localiza-se no distrito do Porto, Concelho de Santo Tirso, Portugal, numa região denominada Vale do Ave que, neste momento, e segundo o Projeto Educativo (2011-2013: 9), apresenta uma taxa de desemprego de $22 \%$ e uma debilidade econômica que faz $47 \%$ dos alunos demandarem benefícios da ação social escolar ${ }^{2}$.

Para analisar as relações de poder que se desenvolvem na escola, construímos, metodologicamente sustentadas, dispositivos de recolha de informação para a obtenção de dados, com os quais conseguimos identificar o tipo de poder(es) que os alunos utilizam no sentido de corroborar/contrariar as regras formais (centralmente definidas), não formais (organizacionalmente determinadas) e mesmo informais (organizacionalmente ativadas) que sobre eles recaem numa tentativa de conformar seus estilos de vida escolar com os princípios de "uma escola perfeitamente governada".

A amostra foi constituída por 13 alunos - 7 de uma turma do $7^{\circ}$ ano de escolaridade, em sua grande maioria com processos de retenção ao longo do percurso escolar, sujeitos a planos de acompanhamento em resultado de retenção repetida e com participação de ocorrências indisciplinares a algumas disciplinas; 6 alunos de uma turma do $9^{\circ}$ ano de escolaridade, com idades ligeiramente abaixo da dos alunos do $7^{\circ}$ ano, sem retenções ao longo do percurso escolar, com sucesso escolar em todas as disciplinas e propostos para quadro de mérito; 8 professores da escola, elementos dos conselhos das duas turmas dos alunos e seus dois respetivos diretores de turma; duas encarregadas de educação - mães de alunos da amostra, uma delas representante dos pais no conselho de classe de uma das turmas da amostra e, simultaneamente, no Conselho Pedagógico; a outra, representante dos pais nos conselhos da outra turma da amostra e representante da Associação de Pais da escola; 3 assistentes operacionais - 2 pertencentes ao quadro de escola e 1 com contrato individual de trabalho ${ }^{3}$.

Com a técnica de investigação alocada à análise de conteúdo, de cariz categorial, de documentos (arquivos legislativos específicos externos e internos,

\footnotetext{
${ }^{2}$ Modalidade de apoio econômico escalonado destinada aos alunos dos agregados familiares mais desfavorecidos, aliviando os encargos inerentes ao prosseguimento da escolaridade obrigatória.

${ }^{3}$ Aos assistentes operacionais (auxiliares de ação educativa) cabe o exercício de funções de apoio geral à organização escolar, incluindo o apoio logístico à direção, aos departamentos e docentes e a observação dos comportamentos das crianças e adolescentes nos vários espaços escolares, sobretudo no recreio. Porque circulam por toda a escola, os assistentes operacionais são detentores de informação privilegiada sobre os acontecimentos da/na escola.
} 
atas dos conselhos de turma, relatórios), dos discursos dos atores patentes em entrevistas semiestruturadas, damos conta de um estudo com o qual pretendemos dar voz aos alunos, tendo em conta as relações que estes mantêm com os professores, os assistentes operacionais, o diretor (que se recusou a participar na investigação) e outros elementos da comunidade escolar, assim averiguando suas opiniões e perceções sobre as normas, práticas, os desvios, constrangimentos. Tudo isto nos permite questionar a escola a partir das várias configurações estruturais que esta adquire quando atravessada por várias relações de poder e apresentar sugestões para que se configure como um espaço educativo de inclusão de todos os membros que a frequentam ou nela trabalham.

\section{Relações de poder na escola: perspectivas teóricas}

A análise da problemática das relações de poder nas organizações educativas tem afirmado-se como imprescindível para uma compreensão heurística de seu funcionamento. De fato,

[...] as organizações [...] são susceptíveis de ser analisadas em termos de relações de poder ou de micropoderes e a escola, como organização que é, só pode constituir-se e, portanto, também sociologicamente entender-se, enquanto contexto social atravessado por relações de poder. (AFONSO, 1991b, p.134).

Numa configuração organizacional permeada por relações de poder, muito se tem reiterado a ideia de que a escola é uma organização burocrática. A escola, como organização burocrática que é, reflete a parte visível e oficial da organização - a que está consagrada na legislação e nos regulamentos, exatamente a que determina a atribuição de competências e distribui tarefas para a consecução de metas específicas (ETZIONI, 1974, p. 19). Sendo uma organização burocrática, o tipo de poder predominante que nela opera é o poder normativo, sendo contudo necessário salientar que:

A escola é uma organização normativa menos típica, uma vez que as elites organizacionais têm menos poder de liderança, desempenhando os líderes informais um papel mais central no controlo dos participantes dos níveis inferiores, a que não será alheio o facto, do grau de integração dos membros na atividade organizacional ser mais baixo e, paralelamente, existir um maior grau de diferenciação na constituição da organização. (ETZIONI, 1974, p. 148-150).

Se na análise da escola nos ativermos, simultaneamente, ao "plano das orientações para a ação" e ao "plano da ação organizacional"; em suma, se nesta análise contemplarmos "a face formal e a face informal da escola como organização" (LIMA, 1998; 2003), veremos como apesar de a escola ser uma 
organização que é "controlada centralmente pelo Estado, em que a mobilização de interesses de grupos antagónicos se pode tornar [...] difícil”, algum grau de liberdade os atores educativos possuem para encontrar nas margens das normas instituídas brechas pelas quais emergem normas instituintes, "que resultam da capacidade estratégica dos atores escolares [...], mas também, [das] capacidades criativas de inovação e de mudança organizacionalmente sediadas" (LIMA, 1998, p. 66; LIMA, 2003, p. 112, grifo nosso).

Neste registo, a escola é, em termos organizacionais, uma realidade complexa. Sua compreensão crítica só é possível recorrendo ao estudo da organização escolar em ação e não apenas às estruturas formais e oficiais, valendo-se de modelos teóricos que nos permitam focalizar a organização "mapeando e interpretando os choques de racionalidades distintamente ancoradas, acedendo a versões não oficiais da realidade". Até "porque [...] as organizações são sempre as pessoas em interação, e porque os atores escolares dispõem sempre de margens de autonomia relativa [...] mesmo quando esta não se encontra juridicamente consagrada e formalmente reconhecida e regulamentada" (LIMA, 1998, p. 93-163; LIMA, 2003, p. 7-94, grifo do autor). De fato,

[...] os atores escolares não se limitam ao cumprimento sistemático e integral das regras hierarquicamente estabelecidas por alguém, não jogam apenas um jogo com regras dadas a priori, jogam-no com a capacidade estratégica de aplicarem seletivamente as regras disponíveis e mesmo de inventarem e construírem novas regras. (LIMA, 2003, p. 94, grifo do autor).

Em suma, a escola é uma organização formalmente organizada, "condenada a refletir e a reproduzir uma dada orientação hegemónica", uma dada estrutura de autoridade e poder, mas é também uma organização na qual se produzem dinâmicas organizacionais próprias, "não sendo apenas um locus de reprodução, mas também, um locus de produção, admitindo-se que possa constituir-se também como uma instância (auto) organizada, para a produção de regras (não formais e informais)" (LIMA, 1998, p. 159-175, grifo do autor). Deste modo, os processos dinâmicos das organizações são indutores de regras não formais e informais,

[...] que podem, eventualmente, vir a suplantar a força jurídica-normativa [...], seja por via da prática de infidelidades normativas, de acções de resistência mais ou menos clandestinas, ou o exercício político da autonomia, desde logo através das micropolíticas ou de políticas organizacionais e de lógicas de ação localizadas [...], através de processos de legalização a posteriori ou retrospetiva. (LIMA, 2003, p. 94).

Estas regras não formais e informais:

[...] caraterizam-se pela sua natureza não oficial, pela sua existência marcadamente referenciada e localizada. São regras atribuídas de significados sociais e 
simbólicos emergentes das interacções dos indivíduos, grupos e sub-grupos [que tomam] por referência objetivos diversos dos oficiais, interesses comuns e interesses antagónicos e conflituantes na organização, o poder e não a autoridade, a hierarquia sócio-organizacional e não hierarquia formal representada no organigrama, o ator social e menos a ator racional. (LIMA, 1998, p. 167).

Desvirtuado que está o conceito de racionalidade versado no modelo burocrático-racional e o da "racionalidade instrumental", é pertinente, então, que a organização seja olhada pelos princípios patentes em outros modelos (políticos, da ambiguidade, culturais, por exemplo) e com os quais se consiga reequacionar as relações e problemáticas decorrentes da interação dos atores enquanto seres com capacidade de criar e inovar, deixando de ser meros executores de procedimentos pré-definidos, em suma, enquanto atores detentores de poder(es). Esta análise sobre outras racionalidades que não somente a racionalidade burocrática, quando transposta para a análise da organização escolar, permite que se fale na "existência de uma pluralidade de racionalidades e de uma pluralidade de poderes instituintes e instituídos em contexto organizacional" (ROCHA, 2007, p. 256), poderes esses que podem influir na configuração organizacional da escola.

O estudo das relações de poder, em contexto escolar, dando voz aos atores escolares, nomeadamente aos alunos, só é possível por um "olhar dual" sobre a organização em suas vertentes formal e informal e tendo em conta os condicionalismos burocráticos, certamente, mas também as "possibilidades" ambíguas e políticas de atuação. Assim, o sistema de poder como autoridade impositiva tem que ser complementado por outras bases informais de poder e, nesse mesmo contexto, os modelos teóricos de hierarquia, poder e autoridade constituem um desafio para qualquer organização. A especificidade e as características dos comportamentos individuais e grupais determinam um modelo próprio de atuação para as quais concorrem e são determinantes as relações de poder. A vivência dos atores em contexto escolar é fortemente determinada pelas representações, "jogos" e relações de poder de seus protagonistas.

Quando se fala em relações de poder no interior da escola, não se pode deixar de referenciar alguns trabalhos e autores que têm analisado esta questão, nomeadamente pela construção de tipologias e definições de poder aplicadas à Escola e a seus atores (Quadro 1). Trata-se de definições de poder em que este é visto ora como elemento substantivo e se concilia com outros conceitos tendo a "mesma" força conceitual (força, influência, disciplina, normatividade), sendo exercido de forma descendente e hierárquica por um ator ou conjunto de atores sobre outros - poder instituído; ora como verbo em ação, isto é dizendo respeito ao conjunto de "micropoderes" provindos das bases de ação e com o sentido de resistência, contestação, luta, exercidos por isso de forma ascendente, ou pelo menos de forma lateral ou horizontal. A emergência e manifestação de todos 
esses tipos de poder resultam na configuração da organização escolar como locus de operacionalização de múltiplas relações de poder, muitas vezes assimétricas, mas nem sempre. Esta síntese analítica sustenta, em parte, a análise dos dados que num ponto posterior deste trabalho apresentamos.

\section{Quadro 1 - Tipos/Tipologias de Poder(es) na Escola}

\begin{tabular}{|c|c|c|}
\hline Autores & Tipos de Poder & Caracterização Sumária \\
\hline $\begin{array}{l}\text { Émile Durkheim } \\
\text { (1984) }\end{array}$ & $\begin{array}{c}\text { Autoridade/ } \\
\text { Poder Moral/ } \\
\text { Obediência Consentida }\end{array}$ & $\begin{array}{l}\text { "Por autoridade, teremos de entender } \\
\text { ascendente que sobre nós exerce qualquer } \\
\text { poder moral que nos seja reconhecidamente } \\
\text { superior }[. . .] \text {, existe, na autoridade }[. . .] \text { um não } \\
\text { sei quê, que no-lo impõe. É nisso que consiste a } \\
\text { obediência consentida". }\end{array}$ \\
\hline $\begin{array}{l}\text { Talcott Parsons } \\
\qquad(1986)\end{array}$ & Poder & $\begin{array}{l}\text { "a generalizada capacidade de assegurar o } \\
\text { desempenho de obrigações por parte de unidades, } \\
\text { num sistema de organização coletiva, quando as } \\
\text { obrigações são legitimadas com referência ao seu } \\
\text { impacto sobre metas coletivas e onde, no caso de } \\
\text { recalcitrância, há um pressuposto de imposição } \\
\text { de sanções de qualquer que seja a real agência } \\
\text { daquela imposição". }\end{array}$ \\
\hline \multirow{3}{*}{$\begin{array}{l}\text { Max Weber } \\
\quad(1993)\end{array}$} & Poder & $\begin{array}{l}\text { "A probabilidade de impor a própria vontade } \\
\text { dentro de uma relação social, contra toda a } \\
\text { resistência e qualquer que seja o fundamento } \\
\text { dessa probabilidade" - "O poder de A sobre B } \\
\text { é a capacidade de A conseguir que B faça alguma } \\
\text { coisa que ele não teria feito sem a intervenção } \\
\text { de A". }\end{array}$ \\
\hline & $\begin{array}{l}\text { Autoridade - } \\
\text { Dominação Legítima } \\
\text { (Tradicional, } \\
\text { Carismática, Racional) }\end{array}$ & $\begin{array}{l}\text { Poder institucionalizado e oficializado que } \\
\text { tem de ser considerado legítimo por parte de } \\
\text { quem o reconhece: "toda a relação autêntica de } \\
\text { dominação }[. . .] \text { tem de ser legítima, isto é, aceite } \\
\text { por B na sua relação com A". }\end{array}$ \\
\hline & Disciplina & $\begin{array}{l}\text { "probabilidade de, numa multidão dada de } \\
\text { homens, encontrar obediência pronta, automática } \\
\text { e esquemática a uma ordem, em virtude de uma } \\
\text { atitude adestrada [...]. O conceito de "disciplina" } \\
\text { engloba o "treino" da obediência acrítica e sem } \\
\text { resistência de massas". }\end{array}$ \\
\hline \multirow{3}{*}{$\begin{array}{l}\text { Foucault } \\
(2009)\end{array}$} & Poder Disciplinar & "uma relação de fiscalização, definida e regulada". \\
\hline & $\begin{array}{c}\text { Relações de Poder } \\
\text { (poder - micropoderes) }\end{array}$ & $\begin{array}{l}\text { "O poder não é uma instituição e não é uma } \\
\text { estrutura [...]; As relações de poder não estão em } \\
\text { posições de superestrutura [...], elas têm, onde } \\
\text { funcionam, um papel directamente produtor". }\end{array}$ \\
\hline & Resistência & $\begin{array}{l}\text { A resistência é inseparável das relações de poder: } \\
\text { "Onde há poder há resistência". }\end{array}$ \\
\hline
\end{tabular}


continuação

\begin{tabular}{|c|c|c|}
\hline Autores & Tipos de Poder & Caracterização Sumária \\
\hline $\begin{array}{c}\text { Bourdieu e } \\
\text { Passeron (1970) }\end{array}$ & Violência Simbólica & $\begin{array}{l}\text { Imposição de significações tidas como legítimas, } \\
\text { dissimulando as relações de hegemonia que estão } \\
\text { na base de sua força. }\end{array}$ \\
\hline \multirow{3}{*}{$\begin{array}{l}\text { Paulo Freire } \\
(1986), \text { Henry } \\
\text { Giroux (2001) } \\
\text { Tipos de Poder } \\
\text { na Escola }\end{array}$} & Poder & $\begin{array}{l}\text { Formas culturais e ideológicas prevalecentes } \\
\text { tendentes à dominação de uns atores sobre } \\
\text { outros, imprimindo nestes últimos uma "cultura } \\
\text { do silêncio". }\end{array}$ \\
\hline & Resistência & $\begin{array}{l}\text { Práticas que contradizem as formas culturais } \\
\text { e ideológicas prevalecentes e operacionalizam } \\
\text { novas relações de poder indutoras de } \\
\text { transformação e emancipação. }\end{array}$ \\
\hline & Resistência Simbólica & $\begin{array}{l}\text { Quando a resistência fica limitada ao mundo dos } \\
\text { símbolos culturais ligados à forma de vestir, à } \\
\text { linguagem utilizada e a tudo o que forma uma } \\
\text { subcultura. }\end{array}$ \\
\hline \multirow{3}{*}{$\begin{array}{c}\text { Martin Sedano } \\
\text { e Mariana Pérez } \\
\text { (1989) } \\
\text { Circulação do } \\
\text { Poder na Escola }\end{array}$} & $\begin{array}{l}\text { Sentido "descendente } \\
\text { ou hierárquico" }\end{array}$ & $\begin{array}{l}\text { Exercido fundamentalmente pelos órgãos } \\
\text { colocados no topo da hierarquia, que controlam } \\
\text { os níveis inferiores, fazendo cumprir suas ordens. }\end{array}$ \\
\hline & $\begin{array}{l}\text { Sentido "lateral ou } \\
\text { horizontal" }\end{array}$ & $\begin{array}{l}\text { Exercido entre indivíduos ou grupos situados } \\
\text { ao mesmo nível hierárquico, como é o caso dos } \\
\text { departamentos ou estruturas intermédias. }\end{array}$ \\
\hline & Sentido "ascendente" & Exercido fundamentalmente por alunos. \\
\hline \multirow{5}{*}{$\begin{array}{c}\text { Ribeiro e } \\
\text { Bregunci } \\
(1984) \\
\text { Tipos de poder } \\
\text { dos professores }\end{array}$} & Poder de Cargo & Emana da posição oficial dentro da instituição. \\
\hline & Poder Referente & Ligado às características pessoais. \\
\hline & Poder de Especialista & $\begin{array}{l}\text { Reconhecimento e valorização dos } \\
\text { conhecimentos aprofundados de alguém num } \\
\text { determinado domínio. }\end{array}$ \\
\hline & Poder de Recompensa & $\begin{array}{l}\text { Distribuição de recompensas simbólicas: } \\
\text { utilização de estímulos positivos pelo uso sutil da } \\
\text { linguagem, de símbolos, cerimônias. }\end{array}$ \\
\hline & Poder Coercitivo & $\begin{array}{l}\text { Aplicação ou ameaça de aplicação de sanções } \\
\text { sociais. }\end{array}$ \\
\hline \multirow{6}{*}{$\begin{array}{l}\text { João Formosinho } \\
\qquad(1980) \\
\text { Tipos de poder } \\
\text { dos professores }\end{array}$} & $\begin{array}{l}\text { Poder Autoritativo } \\
\text { (Autoridade) }\end{array}$ & $\begin{array}{l}\text { Assenta na posição oficial. É o poder formal ou } \\
\text { poder de cargo. }\end{array}$ \\
\hline & Poder Pessoal & $\begin{array}{l}\text { Ligado às características pessoais, afetivas, } \\
\text { temperamentais e de personalidade. }\end{array}$ \\
\hline & Poder Cognoscitivo & $\begin{array}{l}\text { Ligado à posse de conhecimentos (acadêmico e } \\
\text { pedagógico). }\end{array}$ \\
\hline & $\begin{array}{l}\text { Poder Material } \\
\text { (Remunerativo) }\end{array}$ & Distribuição de recompensas materiais. \\
\hline & $\begin{array}{l}\text { Poder Normativo } \\
\text { (moral /ideológico) }\end{array}$ & $\begin{array}{l}\text { Recurso a normas (morais, religiosas, jurídicas, } \\
\text { profissionais, valores e ideologias). }\end{array}$ \\
\hline & Poder Físico & $\begin{array}{l}\text { Aplicação ou ameaça de aplicação de sanções } \\
\text { (castigos corporais). }\end{array}$ \\
\hline
\end{tabular}


conclusão

\begin{tabular}{|c|c|c|}
\hline Autores & Tipos de Poder & Caracterização Sumária \\
\hline \multirow{4}{*}{$\begin{array}{l}\text { Almerindo } \\
\text { Afonso } \\
(1991 \mathrm{a}, \mathrm{b})\end{array}$} & Poder Legítimo & Assenta na posição oficial. \\
\hline & Poder Coercitivo & $\begin{array}{l}\text { Aplicação ou ameaça de aplicação de sanções } \\
\text { sociais. }\end{array}$ \\
\hline & Poder de Recompensa & Distribuição de recompensas simbólicas. \\
\hline & Poder Referente & Ligado às características pessoais. \\
\hline \multirow{2}{*}{$\begin{array}{l}\text { Tipos de poder } \\
\text { dos professores }\end{array}$} & Poder Especialista & Ligado à posse de conhecimentos. \\
\hline & Poder de Avaliar & $\begin{array}{l}\text { Ligado aos efeitos nefastos da avaliação sobre os } \\
\text { alunos. }\end{array}$ \\
\hline \multirow{6}{*}{$\begin{array}{l}\text { Almerindo } \\
\text { Afonso } \\
(1991 \mathrm{a}, \mathrm{b}) \\
\text { Tipos de poder } \\
\text { dos alunos }\end{array}$} & Poder de Grupo & $\begin{array}{l}\text { Poder informal daqueles alunos que, percebido } \\
\text { o contexto, comunicam entre si e definem } \\
\text { estratégias de ação concertadas. }\end{array}$ \\
\hline & $\begin{array}{l}\text { Poder de Mobilizar } \\
\text { Conjuntos de Interação }\end{array}$ & $\begin{array}{l}\text { Semelhante ao poder de grupo mas com a } \\
\text { formação de subculturas mais duradouras do que } \\
\text { os grupos momentâneos. }\end{array}$ \\
\hline & Poder de Referente & $\begin{array}{l}\text { Características pessoais dos alunos (poder físico, } \\
\text { pessoal e normativo). }\end{array}$ \\
\hline & Poder Normativo & $\begin{array}{l}\text { Recurso a normas (morais, religiosas, jurídicas, } \\
\text { valores e ideologias). }\end{array}$ \\
\hline & $\begin{array}{l}\text { Poder de Perito ou } \\
\text { Resistência }\end{array}$ & $\begin{array}{l}\text { Capacidade para resistir ao saber acadêmico e à } \\
\text { ação pedagógica. }\end{array}$ \\
\hline & $\begin{array}{l}\text { Poder de Incerteza ou } \\
\text { Poder do Executor }\end{array}$ & $\begin{array}{l}\text { Capacidade para perceber e aproveitar as } \\
\text { incertezas (de conhecimento ou de execução) de } \\
\text { quem pretende exercer poder. }\end{array}$ \\
\hline
\end{tabular}

Fonte: Quadro síntese elaborado a partir de Rocha (2007).

A partir das tipologias e dos tipos de poder anteriormente apresentados, podemos fazer algumas considerações sobre as relações de poder na escola, tal como o fizeram os autores dessas tipologias, e outros autores, que constituem referências incontornáveis no que à problemática do(s) poder(es) na escola diz respeito. As concepções de autoridade de Émile Durkheim, de poder de Talcott Parsons, de poder/autoridade de Max Weber, podendo perfeitamente aplicar-se à escola, implicam que se perspectivem cenários de poder não só de legitimação mas também de controle, hierarquia e assimetria entre quem detém a autoridade (um "ator" ou um "coletivo") e quem a considera legítima e, por isso, submete-se a ela. Esse conceito de poder como "dominação legítima", sendo embora um conceito que perpassa em grande parte de estudos, produzidos, sobretudo, até a década 1970, nos mais variados âmbitos de produção acadêmica, tem sofrido críticas e reformulações diversas.

Existem na escola formas de "obediência consentida", de "obediência acrítica", entre muitas outras formas resultantes de processos de "imposição", 
de "dominação". Não raras vezes, essas formas de dominação atingem vetores de "violência simbólica", defendem os teóricos da reprodução social e cultural. Nesse último registro, a escola, que deveria ser neutra, distribui desigualmente o capital simbólico entre as classes e os grupos sociais. Então,

toda [a] ação pedagógica é objetivamente uma violência enquanto imposição, por um poder arbitrário, de um poder arbitrário cultural [...]. Dito de outra maneira, o alcance dessas proposições encontra-se definido pelo facto de que elas convêm a toda [a] formação social, entendida como um sistema de relações de força e de sentido entre grupos ou classes. [Assim], a ação pedagógica escolar [...] reproduz a cultura dominante, [que] deste modo [reproduz] a estrutura das relações de força, $[\ldots]$ onde o sistema de ensino dominante tende a assegurar-se do monopólio da violência simbólica legítima. (BOURDIEU; PASSERON, 1975, p. 19-20-21).

A "violência simbólica" permitiu que, em França, por exemplo:

até ao final da década de 50, os estabelecimentos de ensino secundário vive[ssem] uma estabilidade [...] fundada na eliminação precoce e brutal dos meninos de famílias culturalmente desfavorecidas, [o que] era em geral aceite pelas crianças que a padeciam e pelas famílias, já que parecia fundada unicamente sobre os dons e os méritos dos escolhidos: aqueles que a escola não queria acabavam, convencendo-se (graças à própria Escola) que não queriam a Escola. (BOURDIEU; CHAMPAGNE, 1999, p. 481).

Aos culturalmente desfavorecidos mas que, apesar de tudo, permaneciam na escola, Bourdieu e Champagne (1999) designam "os excluídos do interior", ou seja, aqueles que a escola exclui, mantendo-os dentro dela, mas nas vias socialmente mais desvalorizadas.

No âmbito das perspetivas pós-estruturalistas e pós-modernas, Michel Foucault (2009, p. 170-172) defende que "uma relação de fiscalização, definida e regulada, está inserida na essência da prática do ensino: não como uma peça trazida ou adjacente, mas um mecanismo que lhe é inerente e que multiplica a sua essência". Pergunta o autor: "Devemos ainda nos admirar que a prisão se pareça com as fábricas, com as escolas, com os quartéis, com os hospitais, e todos se pareçam com as prisões?" Sua própria resposta é a de que vigora na escola um tipo de poder particular: o poder disciplinar que se pode traduzir num poder de vigilância hierarquizada. Pois:

[...] Na oficina, na escola, no exercito funciona como repressora toda uma micropenalidade do tempo (atrasos, ausências, interrupções das tarefas), da atividade (desatenção, [...], da maneira de ser (grosseira, desobediência), dos discursos (tagarelice, insolência), do corpo (atitudes incorretas, gestos não conformes, sujeira), da sexualidade (imodéstia, indecência). Ao mesmo tempo é utilizada, a título de punição, toda uma série de processos subtis, que vão do 
castigo físico leve a privações ligeiras e a pequenas humilhações... levando ao extremo, que tudo possa servir para punir a mínima coisa; que cada individuo se encontre preso numa universalidade punível - punidora. (FOUCAULT, 2009, p. 170-172).

Nesta linha de pensamento, a escola como organização tem mobilizado processos de fiscalização mais ou menos acentuados, enquanto possuidora de um conjunto de valores que se "alimentam" da letra da lei, dos programas curriculares e de uma panóplia de regras escritas. Em suma, uma escola "imobilizada no funcionamento de um poder extensivo que age de maneira diversa sobre todos os corpos individuais - é a utopia de [uma escola] perfeitamente governada" (FOUCAULT, 2009, p. 189), uma utopia que, aliás, tem merecido tentativas de operacionalização mormente por meio dos professores, gestores intermédios, diretores e de outros agentes condutores do processo educativo. Os alunos têm-se constituído receptáculos essenciais desse mesmo dispositivo disciplinar e, embora não tecendo estrategicamente e taticamente uma "rede de antidisciplina" (CERTEAU, 1998, p. 42), não deixam de contra ele se imporem, numa relação assimétrica, é certo, mas perturbadora do "normal" funcionamento da organização escolar.

Michel Crozier e Erhard Friedberg (1977, p. 65), no âmbito da análise das organizações, alertam para o caráter relacional do poder: "Agir sobre o outro é entrar em relação com ele, e é nesta relação que se desenvolve o poder de uma pessoa A sobre uma pessoa B. O poder é então uma relação e não um atributo dos atores". Michel Foucault (2009) criticará as dimensões de dominação do biopoder e poder disciplinar e pugnará por defender que "onde há poder, há resistência".

Foi com conceções heurísticas de poder, tal como a de Foucault, que as perspectivas do "construtivismo estruturalista", normalmente designadas "teorias da reprodução", têm sido criticadas sobretudo no que diz respeito à necessidade de esclarecer seus limites conceptuais. A crítica de que falamos também tem sido efetuada pelos teóricos da pedagogia crítica que consideram, entre outros aspetos, que à análise de Pierre Bourdieu "falta a noção de que a cultura é tanto um processo estruturador, quanto transformador” (GIROUX, 1986, p. 125).

Os teóricos da pedagogia crítica, com a análise que efetuam do ciclo vicioso da reprodução social da desigualdade vão defender, então, que os parâmetros teóricos [da nova sociologia] têm permanecido restritos a noções unilaterais de poder e ação humana e que estas noções precisam ser reconstruídas a fim de que o fundamento para uma pedagogia crítica possa emergir. Explicitando melhor, esses "enfoques", ao mesmo tempo que mostram

[...] como o poder é utilizado para mediar entre as escolas e os interesses do capital [e] focalizam como as escolas utilizam seus recursos materiais e 
ideológicos para reproduzir as relações sociais e atitudes necessárias para manter as divisões sociais do trabalho [...] ainda permanecem situados dentro de uma problemática que em última instância apoia ao invés de desafiar a lógica da ordem vigente [porque] noções tais como as de luta, diversidade e ação humana ficam perdidas em uma visão reducionista da natureza humana e da história. (GIROUX, 1986, p. 106 e seguintes).

Em contraposição, uma das ideias básicas da pedagogia crítica, advinda, aliás, das chamadas "teorias da resistência", é que se deve pôr no centro da análise sociológica a atividade dos atores sociais e sua capacidade de aceitarem, resistirem ou mediarem a dinâmica estrutural da escola e sociedade, até porque o poder não é exercido apenas como um modo de dominação mas também como um ato de resistência. Diz Paulo Freire (1977, p. 36): "Considero que o tema fundamental da nossa época é o da dominação que supõe o seu contrário, o tema da libertação como objetivo que é preciso alcançar".

Nesta linha de pensamento, não se pode ver os alunos como receptáculos passivos de mensagens sociais pré-concebidas, até porque a cultura de origem dos alunos medeia o processo de significados veiculados pela escola, induzindo à "reinterpretação por parte do estudante" que, "na melhor das hipóteses", procede a "uma aceitação parcial do que é veiculado e, frequentemente, a uma rejeição, pura e simples, dos significados planificados e não planificados das escolas" (APPLE, 2001, p. 55).

Assim, o poder instituído no espaço escolar tem de confrontar-se mais com formas de resistência que não "resistência simbólica", isto é, a luta fica muitas vezes limitada ao mundo dos símbolos culturais ligados à forma de vestir, à linguagem utilizada e a tudo que dê um estilo "juvenil", o que em tudo alude a uma subcultura. Essas manifestações de "contrapoder" podem ser vistas como formas de não concordância com as regras e normas instituídas pela organização escolar (GIROUX, 2001, p. 252).

Paulo Freire, ao falar do poder da estrutura escolar sobre a cultura popular, chama a atenção para um processo a que chama:

[...] a cultura do silêncio [que possui] várias dimensões, inclusivamente uma reação agressiva dos alunos [...]. A pedagogia oficial os constrói como personagens passivos/agressivos. Depois de anos em aulas com soníferas falas professorais, muitos se tornaram não - participantes [...]. Esse retraimento do estudante pode ser simplesmente passivo ou pode ser um raivoso silêncio reprimido. (FREIRE, 1986, p. 148).

Inserido em várias relações e dimensões, assim opera o poder. Trata-se, em suma, de uma rede de poderes em que se verifica a "circulação" dos mesmos em vários sentidos: "descendente ou hierárquico"; "lateral ou horizontal" 
e "ascendente", "admitindo-se como desejável a sua coexistência e complementaridade” na escola como organização. (SEDANO; PÉREZ, 1989, p. 132).

Alguns trabalhos existentes reportam-se, especificamente, ao poder dos professores. João Formosinho (1980) apresenta "as bases do poder do professor" mostrando como:

[...] os atos de poder utilizam componentes de mais de que um tipo. Se olharmos para o total do poder disponível num grupo ou num indivíduo constatamos que ele é uma combinação dos vários tipos [de poder] [...] que ele se apoia em várias bases [...] de poder [de modo a abrigar todas as situações possíveis no interior dos muros da escola]. O poder normativo [...] não é fácil de usar e uma das suas principais dificuldades é que para ser operante é necessário que [professor e alunos] partilhem o mesmo código. [...] Dada essa dificuldade não é de estranhar que o professor atual [continue] a ser o transmissor de conhecimentos mais do que o formador e [o] socializador [...]. (FORMOSINHO, 1980, p. 304-308, grifo do autor).

Embora pese a combinação dos vários tipos de poder, o poder autoritativo - ou a autoridade que se baseia "na posição oficial de superioridade formal de A em relação a B" - continua a ser uma das bases essenciais dos poderes dos professores, defende João Formosinho (1980, p. 312-313). Explicitando concretamente as relações de poder que se pode estabelecer entre professores e alunos, Almerindo Afonso (1991a) mostra como essas se apresentam tendencialmente assimétricas, ou seja, o poder do professor é mais forte do que o dos alunos. $\mathrm{Na}$ linha de Michel Crozier (1981, p. 240), que pensa que "cada membro de uma organização, mesmo o mais humilde dispõe de [...] de um mínimo de poder", a análise de Almerindo Afonso (1991a, p. 33-141) leva-o a clarificar que:

[...] os professores não são destituídos de poder, também não são donos de um poder absoluto. [...]. Entre outras razões bastaria referir que os alunos, sendo atores tão ou mais importantes que os professores no processo educativo, [...] são também em maior número que os professores - o que, só por si, é uma importante fonte de poder [...]. O poder do professor será tanto maior quanto mais diversificadas forem as bases em que ele se sustentar e quanto maior for a congruência entre as bases de poder do professor e as finalidades do nível do sistema educativo em que exerça a sua atividade [...].

Segundo Almerindo Afonso (1991a, p. 26-31) "em escolas de adolescentes parece ser o poder normativo-social [...] que apresenta maiores probabilidades de ser utilizado com êxito por parte do professor". Este poder refere-se à manipulação da autoestima dos alunos no sentido descendente ou hierárquico, ou é exercido sobre o "grupo ao qual o [aluno] pertence ou deseja pertencer" de forma a obter sua concordância e resposta positiva. Na esteira deste investigador, "todas as escolas asseguram a submissão ao combinar o poder normativo e o 
poder coercitivo, variando apenas a ênfase em um ou outro tipo de poder, consoante a faixa etária" dos alunos. Para o mesmo autor, o poder autoritativo ou autoridade "decorre do facto de o professor estar oficial e legalmente respaldado para exercer a sua atividade numa organização formal que é a escola. Este poder, embora confira ao professor uma superioridade formal, nem sempre é suficiente para manter uma relação educativa eficaz". Pois, nesta relação de poder,

[...] é necessário que os alunos reconheçam o professor como autoridade, [...], como alguém que, independentemente de outras bases de poder [...], deve ser obedecido. Esta constatação remete, por um lado, para a necessidade de pensar a própria eficácia de autoridade a partir do contexto educativo em que se exerce - a obediência à autoridade será tanto mais efectiva quanto mais o ambiente social e organizacional a considerar como um valor em si; e, por outro lado, aumentará a sua aceitação na medida em que tender a associar-se a outras bases de poder. (AFONSO, 1991a, p. 26-31).

Conclui o autor (AFONSO, 1991a, p. 145-146) que "a sala de aula, não raras vezes, oculta relações interpessoais conflitivas, devido às formas de imposição e exercício do(s) poder(es) dos atores, e às próprias caraterísticas do contexto 'sumamente normativo' em que se desenvolvem." Num outro texto de referência, Almerindo Afonso (1991b, p. 41-44) mostra como "o poder de avaliar" é mais um dos poderes dos professores que contribui para a acentuação da relação assimétrica de poder entre eles e os alunos mas, simultaneamente, também defende uma maior "reciprocidade na relação pedagógica", por meio de uma maior participação dos alunos no processo avaliativo, por exemplo.

No que pese a existência de relações tendencialmente assimétricas entre professores e alunos, em outras investigações, nomeadamente a de Sara Delamont (1987), tem sido posto em evidência que:

[...] quando duas [ou mais] pessoas entram em interação, cada uma delas está constantemente a interpretar os seus atos e os da [s] outra [s] e reagindo, voltando a interpretar, voltando a reagir. [...]. Nestas acções conjuntas [...], é importante que se não perca de vista a dimensão do poder. Em qualquer área da vida humana, alguns dos participantes podem ter maior poder que outros - ficando habilitados a impor a sua definição da situação aos demais. (DELAMONT, 1987, p. 38).

Neste registro, Sara Delamont (1987, p. 90) reitera que

[...] o poder dos alunos está directamente relacionado com o número de colegas que eles podem mobilizar contra o professor. Para ter poder, um aluno necessita do auxílio dos amigos. É desta forma informal que os alunos fazem emergir a sua resistência e capacidade de influência nos seus pares em contexto escolar. 
Tem sido de fato defendido que "a principal fonte de poder dos alunos é o grupo" (AFONSO, 1991a, p. 34), um grupo que "em qualquer momento é constituído por aqueles alunos que percebem o que está a acontecer de uma maneira semelhante, comunicam uns com os outros e definem em conjunto a ação adequada" (FURLONG apud DELAMONT, 1987, p. 91). Desta feita,

[...] os conceitos de conjunto de interação e o de subcultura são complementares e devem ser olhados como importante forma e fonte de poder dos alunos. Assim, o poder de um aluno pode avaliar-se pela sua capacidade de mobilizar conjuntos de interação, mas esta capacidade pode estar associada a outros fatores, entre os quais o facto desse mesmo aluno pertencer, eventualmente, a subculturas específicas. (AFONSO, 1991a, p. 34-35, grifo do autor).

A análise das relações de poder na escola é premente hoje quando, por exemplo em Portugal, temos a seguinte notícia:

INDISCIPLINA. Escolas declaram-se impotentes para lidar com alunos problemáticos" ... Com a crise a traduzir-se num aumento da indisciplina, cada vez mais pessoas reclamam a retirada dos estudantes problemáticos das escolas regulares. O Estatuto do Aluno agilizou as penalizações, mas não responde aos problemas que começam nas famílias. Ministério diz que é cedo para alterações. (JORNAL PÚBLICO, 13 de fevereiro de 2013).

\section{Relações de poder na escola Lua-Sol: análise de dados}

O contexto organizacional, objeto de nosso estudo, é pautado por regras formais dimanadas do enquadramento jurídico-normativo da administração educacional e das orientações para a ação (documentos externos), por regras não formais elaboradas em contexto organizacional (documentos internos) e por regras informais que os mais variados atores produzem no quotidiano da ação organizacional. No plano da ação organizacional, assiste-se simultaneamente a uma reprodução das orientações para a ação e a uma produção de novas regras, conformes os interesses e as expectativas dos atores. Tal como em outros estudos, também neste se pode comprovar a existência de inconsistências e desconexões entre regras e práticas, estruturas e atividades, objetivos e procedimentos, decisões e realizações. Entre muitas inconsistências e desconexões que poderíamos apresentar, atendamos às seguintes, uma vez que se relacionam com o principal alvo de nosso estudo: os alunos.

Em primeiro lugar, há que dizê-lo: a forma de participação dos pais e alunos está omissa no Regulamento Interno (2010), o que é desconexo com o estipulado no Decreto-lei 75/2008b, de 22 de abril, no qual claramente é enunciado que o "Regulamento Interno de escola deve definir a forma dessa participação". Tal regulamento refere somente que os alunos têm o direito de "Conhecer o 
Regulamento Interno", o que fica muito aquém do estipulado na Lei 3/2008a, que prevê a "participação dos alunos na elaboração do Regulamento Interno da Escola". Veja-se que, no documento produzido no âmbito da avaliação interna (2010), no que concerne ao Critério "Planeamento e Estratégia" se atribui a "classificação de insuficiente" à

Participação de Encarregados de Educação [...] no processo de elaboração/ revisão dos documentos norteadores [e à] Participação de alunos e encarregados de educação, no processo de avaliação do Plano Anual de Atividades [...] com o intuito de ser apurada a necessidade de reformulação e/ou adaptação dos mesmos. (REGULAMENTO INTERNO, 2010).

O Regulamento Interno (2010) elenca uma série de direitos para os alunos. Contudo, após a leitura do artigo $13^{\circ}$ da Lei 3/2008a, de 18 de Janeiro, no que concerne aos direitos dos alunos do ensino não superior, verificamos que o fundamental de uma instituição escolar, no que concerne à sua missão como escola pública, não está garantido neste documento. Para além disso, este mesmo Regulamento Interno (2010) triplica o rol de obrigações e as medidas coercivas e as disciplinares sancionatórias, em caso de infração, que se delineiam no artigo $15^{\circ}$ da Lei $3 / 2008$ a, e nele não se faz nenhuma alusão às finalidades destas medidas corretivas e sancionatórias, nomeadamente ao nível pedagógico de prevenção e de integração, como aliás se estipula que deve ser feito na lei anteriormente mencionada. Um outro aspeto particular: a Lei 3/2008a, de 18 de Janeiro prevê a

[...] participação dos alunos na elaboração do Regulamento Interno da Escola, conhecê-lo e ser informado, em termos adequados à sua idade e ao ano frequentado, sobre todos os assuntos que justificadamente sejam do seu interesse, nomeadamente, [...] sobre todas as atividades e iniciativas relativas ao projeto educativo da escola.

Os alunos, quando questionados sobre sua concordância relativamente ao significado do teor do texto referente aos seus direitos e deveres enunciados no Regulamento Interno, afirmam que simplesmente tomaram "conhecimento deles com a diretora de turma" (Entrevista - aluno 3), e que os mesmos lhes foram "apresentados como os direitos e os deveres a cumprir. Nunca nos pediram sugestões" (Entrevista - aluna 10). Constatamos ainda que os alunos possuem uma visão crítica relativamente aos seus deveres, quando referem que "Não concordo com eles. Por exemplo, não poder mascar chicletes nas aulas e na hora de almoço, não podemos circular pela escola. Temos que estar só no polivalente" (Entrevista - aluna 4); ou então, "Não concordo com alguns. Por exemplo mascar chicletes na aula. Não sei que mal isso tem. Usar boné, também, não sei que mal isso tem" (Entrevista - aluno 5). 
Interrogados sobre a importância de haver uma associação de estudantes na escola, os alunos entrevistados não corroboraram a opinião do diretor, "que isso era só fachada" (Entrevista - aluno 5). Segundo esses alunos, esta estrutura escolar permitiria "terem mais voz ativa" (entrevista/aluna 7) e, assim, usarem seu "poder de influência" na tomada de decisão em matérias ou assuntos de seu interesse. Referem que "A escola é para os alunos. Devíamos ser ouvidos" (Entrevista - aluno 11), para "poderem participar e terem ideias para novas atividades e, por exemplo, em vez de ser só uma turma, assim ser todas. Acho que se os alunos se envolvessem [nas] atividades que supostamente se iam criar, [...] era uma maneira de estarem" (Entrevista - aluna 7), "mais motivados" (Entrevista - aluna 13).

Ainda no entendimento dos alunos entrevistados, sua participação ativa na escola revela-se crucial, para "dar opiniões" (Entrevista - aluno 8) sobre o "funcionamento da escola, como ler poemas na biblioteca e mais atividades nos tempos livres" (Entrevista - aluno 12). Isto estreitaria as relações de comunicação entre os vários atores escolares, porque "Nós já sabemos o que queremos e era melhor" (Entrevista - aluna 4). Assim, "é vir para a escola cedo e ir para casa tarde" (Entrevista - aluno 3). Alguns dos alunos entrevistados referem mesmo que quando têm uma sugestão a dar sobre o funcionamento da escola: "Não há ninguém para nos ouvir" (Entrevista - aluno 2); "Não existe esse hábito nesta escola" (Entrevista - aluna 10); "Não há quem nos ouça”" (Entrevista - aluna 9); "Ninguém nos ouve, então quando algum tem fama..." (Entrevista - aluno 11).

Relativamente a estas questões da participação dos alunos na escola, os professores referem que as sugestões que os delegados e subdelegados de turma levam para os conselhos de turma são tomadas em consideração "por alguns professores" (Entrevista - professora 7). Contudo, grande parte dos professores salienta: "Pela Direção acho que não" (Entrevista - professor 5), "Ele [o diretor] não tem muita relação com os alunos" (Entrevista - professora 3) aliás, "não sei se alguma vez chegou alguma queixa ao Diretor" (Entrevista - professor 8), apesar de os problemas serem registrados:

[...] em ata, nomeadamente em relação ao horário (semanal) e de terem pouco tempo para almoçar. De terem que vir para as 8:20, quando as aulas começam às 10 horas e depois terem que passar o dia todo na escola até às 18:30, às vezes com furos pelo meio. Com horário sobrecarregado. Isso foi deixado em ata mas não se fez nada (Entrevista - professora 1).

Podemos ainda apurar que a totalidade dos professores da presente amostra deu sugestões ao Diretor para melhorar o funcionamento da escola. Dizem estes professores: 
As reclamações dos encarregados de educação que transmiti como diretora de turma e registadas em duas atas, não foram tomados em consideração. Os que ele (O Diretor) me disse é que era complicado mexer, agora, nos horários. Não se fez nada que pudesse inverter a situação (Entrevista - professora 1); Ui, ui sem conta. Sobre os horários, sobre a distribuição letiva, ocupação de espaços. [...] não sei se esses critérios definidos pelo Conselho Pedagógico são os mais corretos. [...] os professores estão mais interessados na defesa dos seus interesses do que nos interesses dos alunos e da escola. Aí, culpo a Direção da escola [...]. Preocupo-me com os horários dos alunos que por causa de alguns professores, [...] ficando o turno da manhã superlotado e o turno da tarde só com algumas turmas. [...] a Sala de Estudo não há. Inventam-se espaços. Numa Biblioteca, onde está a Sala de Estudo, onde se confunde tudo. Estes espaços são pensados a posteriori dos horários (Entrevista - professor 2); Várias. Em conversas informais, vou sugerindo. Olha, quando começo a ver tanta burocracia, já sugeri: 50\% das turmas obrigatoriamente não ter esta papelada toda, projeto curricular de turma, planos de recuperação e acompanhamento, estes relatórios sem fim. Só tínhamos que nos preocupar em dar as aulas. E nas outras turmas fazíamos os planos todos e os relatórios todos, tudo direitinho. No final do ano fazíamos uma prova de aferição e vamos ver o sucesso escolar. A partir daí tínhamos uma referência. Será que o excesso de burocracia, o excesso de papéis, planos de recuperação, planos de acompanhamento, na prática, eu não vejo benefícios. Eu já sei que com alguns alunos tenho que trabalhar de maneira diferente e com outros, eu sei que tudo que lhes digo eles vão cumprir. Os outros, vou ter que bater, bater, bater na mesma tecla e se calhar nem assim. Chego ao final do ano tenho que fazer um grande relatório e, depois para que servem. São lidos, quando são, em conselhos de turma e depois, no final do ano, são deitados ao lixo. [Antes disso], servem, servem para tirar o aluno $\mathrm{X}$ da turma $\mathrm{Y}$, porque não pode estar junto do aluno $\mathrm{H}$ e mais nada. Depois junta-se o aluno X com o aluno I da turma $\mathrm{F}$, e os problemas continuam. [...] é assim que se formam turmas explosivas. Ou então formam-se turmas de elite, que eu não concordo. As turmas do meu ponto de vista devem ser heterogéneas, porque uns alunos puxam uns pelos outros (Entrevista - professora 3); Já dei algumas...Choca-me as substituições da forma como foram introduzidas e [...] são abordadas. A escola devia ter locais com várias atividades para que os alunos [...] de acordo com os seus interesses, [...]. Há vários professores que comungam das mesmas ideias [...] (Entrevista - professora 6).

Estas opções organizacionais da escola são percecionadas pelos professores como uma forma desequilibrada que o Diretor encontrou para maniatar toda a ação escolar e, no que a estes atores educativos diz respeito, exigir que trabalhem "para a estatística. A estatística é muito importante [ironia]. Neste momento acho que temos que esquecer a estatística e bater no fundo" (Entrevista - professora 3). Ainda em matéria das relações que o diretor mantém com 
os alunos, no relatório da avaliação externa do Agrupamento de Escolas, em que a escola Lua-Sol é a escola-sede, elaborado pela Inspeção-Geral da Educação (2009-2010: 6), no domínio “Organização e Gestão Escolar”, explicita-se que o Diretor

[...] tem promovido reuniões com os alunos delegados e subdelegados de turma para os auscultar sobre [...] a limpeza das instalações sanitárias e dos espaços escolares. Apesar destes contributos, não existe uma cultura que estimule a participação [...] ativa dos alunos na vida escolar, traduzida, nomeadamente na discussão dos documentos estruturantes [...], na apresentação de propostas de atividades e na constituição de uma Assembleia de Delegados/ Associação de Estudantes.

Segundo os alunos sujeitos a processos disciplinares e retenções ao longo de seu percurso escolar, as sugestões que os delegados e subdelegados de turma levam para os conselhos de turma não são tomadas em consideração pelos professores da turma, referindo que seu valor na escola se reduz aos alunos "mais direitinhos" (Entrevista - aluno 3), pois "A Stora (diretora de turma) só pergunta aos melhores alunos, os que têm mais capacidades para darem sugestões. Aos outros não" (Entrevista - aluna 4). Assim, segundo estes alunos: "Depende do delegado. Se for um delegado como eu, sou delegado, não o ouvem. [Pensam...] aquele porta-se mal..." (Entrevista - aluno 2), e "Como usamos brincos ninguém nos leva a sério” (Entrevista - aluno 3).

Perante os "ditos problemas" existentes na escola, e nomeadamente na sala de aula, no ano letivo 2009-2010, criou-se o Gabinete de Orientação e Prevenção da Indisciplina (GOPI) com o objetivo de "diminuir a indisciplina e reorientar [...] os casos problemáticos". É de referir que o GOPI entrou em funcionamento antes de ser objeto de regulamentação no Regulamento Interno da escola (2010) e que o mesmo não estava previsto em nenhum normativo externo. Diga-se, também, que em seus objetivos está implícita a "censura disciplinar do comportamento assumido pelo aluno" em tempo útil, tendo-se então a escola antecipado ao estipulado no Novo Estatuto do Aluno (ponto 1, artigo $28^{\circ}$ da Lei n ${ }^{\circ} 51 / 2012$, de 5 de setembro), tendo, em suma, a escola tentado reforçar um poder informal sobre os alunos antes de esse poder ser formalmente estipulado por lei.

Segundo os atores escolares docentes e discentes, em contexto de sala de aula, as formas de resolução dos problemas de comportamento dos alunos encontram-se muito centradas no ato de os "Expulsar [...] das aulas" (Entrevista - aluno 1) e em "mandar logo para o GOPI" (Entrevista - aluno 3). No relatório desta estrutura escolar (2010) é referido que "Para a maioria dos inquiridos, o GOPI teve um efeito inibidor de comportamentos menos adequados em alguns 
alunos". Contudo, quando por nós questionados, os professores referem que este "poder coercitivo", "poder disciplinar" sobre os alunos "Não diminui a indisciplina" (Entrevista - professor 2). Outras situações há em que "os resultados não são, $[\ldots]$ os que se pretendem, porque o objetivo é levar o aluno [...] [no GOPI], a reconhecer [...] o seu erro" (Entrevista - professora 3), sem apresentação de dinâmicas concretas, que não sejam dinâmicas punitivas, por parte dos professores ou de outros membros da comunidade escolar, para a melhoria dos comportamentos. É “uma estratégia que resulta mais para o professor e para o resto da turma do que propriamente levar o aluno a mudar o comportamento. Acho que é uma treta" (Entrevista - professora 1).

Os alunos com sucesso escolar em todas as disciplinas referem que: “[...], foi uma boa criação. É uma maneira de tentar que a indisciplina diminua mas [...] há aqueles que percebendo que fizeram mal que param, há outros que não" (Entrevista - aluna 7) e "[...] é uma forma de pôr medo aos alunos" (Entrevista - aluna 13). Os alunos que têm problemas de comportamento em contexto de sala de aula referem: "Não sei para que serve o GOPI. É só para nós irmos para lá. Quando eu vou para lá, está lá sempre a professora [nome da professora], ela nem fala comigo. Está no computador a falar no Messenger" (Entrevista - aluno 5). E “[...] ir para o GOPI não é um castigo. É só ficar lá sem fazer nada [...]. Nós não temos medo. A escola é uma seca, só tem de bom os intervalos" (Entrevista - aluno 8).

Na prática, o GOPI é uma estrutura escolar que permite aos professores em sala de aula atualizar seu "poder autoritativo" ou "poder legítimo", e que permite à escola exercer seu "poder disciplinar" sobre os alunos que resistem à ação pedagógica. Porém, muitos desses alunos não legitimam nem o "poder coercitivo" nem tão pouco o "poder cognoscitivo - acadêmico e pedagógico" dos professores e somente cumprem com o formalmente previsto, preenchendo as grelhas do GOPI. Passada a fase formal, os alunos reincidem nos comportamentos vistos como não apropriados pelos professores, fazendo-o até como forma de provocação.

Os elementos discentes da amostra com um percurso escolar descontínuo referem que um dos fatores que determina os conflitos entre professores e os alunos, em contexto de sala de aula, e que faz que os professores mandem os alunos para o GOPI, é o "poder de referente" de alguns alunos sobre o grupo:

Nas aulas em que o Gato e o Vítor não estão era um silêncio [...]. Podíamos estar com atenção, mas quando eles chegam, começam a falar e desestabilizam [...]. Os professores bem querem dar as aulas mas eles não deixam (Entrevista - aluno 8); Se está o Gato e o Vítor é como um imã, todos [os alunos] estão com atenção a tudo que eles fazem (Entrevista - aluno 1). 
Estes mesmos alunos percecionam a relação que os professores mantêm com eles desta forma: "Como andamos com brincos e as calças rasgadas somos olhados mal" (Entrevista - aluno 3). Este desiderato é entendido pelos alunos como uma forma de os rotular, a partir da utilização do "poder normativo" por parte dos professores, porque "os [...] que têm mais fama, qualquer coisinha [vão] para o GOPI” (Entrevista - aluno 3). Questionados sobre se os castigos/ punições disciplinares alteram os comportamentos desviantes, os alunos referem que não, “comigo parece que é pior com os castigos. Há professores que dá pica empetar (implicar) com eles. Os professores comigo não conseguem tudo o que querem [...]. Com alguns alunos conseguem. Comigo não” (Entrevista - aluna 4).

Neste registro comportamental, o "poder de grupo" de alguns alunos verifica-se quando conseguem o apoio dos colegas da turma "para enfrentarem o professor" (Entrevista - aluno 3). Porque "Quando o professor faz alguma coisa a um aluno da turma, que nós não gostamos, somos todos por um e um por todos" (Entrevista - aluno 5) E, "Nós, não deixamos, se quisermos os professores dar as aulas [...]. Acontece mais com professoras, porque são em maior número. Mas geralmente acontece com o professor de Matemática” (Entrevista - aluna 4).

Então, tipos de poder tais como o "poder de especialista", o "poder cognoscitivo" dos professores são contrariadas pelos alunos quando, individualmente, convocam seu "poder de perito ou resistência" ou aproveitam o "poder de referente" de alguns alunos, com elevado estatuto sociométrico sobre seus colegas, ou ainda, o que acontece muitas vezes, como vimos, apoiam-se no "poder de grupo" para definir estratégias de recusa de aprendizagem concertadas. Assim, os alunos conseguem:

[...] desconcertar e descontrolar [o professor]. [...] É impossível dar aulas. Tentei todos os métodos, mas não conseguia dar as aulas. Eles pura e simplesmente não deixavam, [...]. Se um professor não tiver os pés assentes no chão entra em parafuso [...]. Eles funcionam em grupo, [...] tipo Dartanham, um por todos e todos por um. Eu olhava para eles e via que estavam a fazer asneira e na minha cara diziam: Eu, eu não. Eu não fiz nada professor (Entrevista - professor 2).

Pouco frequentemente é utilizado o "poder físico" por parte dos alunos:

[...] uma vez [uma professora] puxou-me as orelhas. Eu ia a sair da sala, ela não me deixou, depois queria que eu saísse, eu não saía, foi então que a encostei à parede ...só. Eu não disse a ninguém, ela não disse a ninguém e foi assim (Entrevista - aluno 3).

O processo ensino-aprendizagem não é neutro. O "poder de cargo" dos professores, embora necessário para determinar as regras de trabalho, traduz-se 
muitas vezes em "marcar falta ao primeiro tempo" e colocar os "alunos fracos numa mesa ao fundo da sala" (Entrevista - aluna 4). A atenção dos professores está essencialmente centrada nos "bons alunos", sendo que "os rebeldes" experimentam um sistema institucionalizado de diferenciação de status baseado em seu fraco desempenho escolar, seus comportamentos, sua linguagem, sua cultura de origem. Segundo os alunos, a organização escolar só valoriza e envolve "aqueles alunos ... aqueles mais...mais certinhos. Os outros só porque têm um brinco, são drogados" (Entrevista - aluno 3).

Diga-se a este propósito que diante da trajetória escolar descontínua de alguns alunos, em conselhos de turma de avaliação sumativa, propôs-se que "os alunos $[\ldots]$ que não transitaram fossem separados $[\ldots]$ e encaminhados para percursos alternativos, $[. .$.$] ou [\ldots]$ indicados para $[. .$.$] uma turma de cursos de$ Educação e Formação" (ata de conselho de turma). Contudo, "os encarregados de educação ${ }^{4}$ não concordaram" (ata conselho de turma). Deste modo, estes alunos foram novamente integrados numa turma do $7^{\circ}$ ano de escolaridade, mas arrumados numa classe homogênea de nível escolar inferior, decisão política da escola que os encarou como os responsáveis pelo seu próprio fracasso escolar.

Todavia, os alunos da amostra com percurso escolar descontínuo valorizam os professores "mais sensíveis, [...] que deixam passar" (Entrevista - aluno 3) e os que utilizam estímulos positivos e fazem uso do "poder de recompensa". Assim aconteceu quando "O professor de Educação Física [...] me deu os parabéns [...]" (entrevista/aluno 3). No entanto, e em geral: "quando nós nos portamos mal [somos punidos] mas quando eu me porto bem ela [diretora de turma] não diz [nada]" (Entrevista - aluno 5). Simultaneamente estes mesmos alunos valorizam o poder de referente ligado às características pessoais do "professor (nome do professor) que puxava por mim [os que] falam conosco e sabem nos ouvir" (Entrevista - aluno 3) e também os que "compreendem os alunos" (entrevista/aluna 4). Estes alunos da amostra valorizam também os conhecimentos científicos dos professores (poder cognitivo ou cognoscitivo) e seus conhecimentos pedagógicos e didáticos na respetiva área do saber. Veja-se que:

[...] a alguns professores, nós pedimos para ir ao quadro e eles fazem de conta que nós não somos ninguém, não ligam nenhum. Alguns professores colocam de parte alguns alunos, colocam-nos numa mesa ao fundo da sala. Outros estão sempre à nossa beira, a ajudar-nos, a verem o que nós não sabemos (Entrevista - aluna 4).

\footnotetext{
${ }^{4}$ Em Portugal, o Ministério da Educação, por meio do Despacho n. ${ }^{\circ} 14$ 026/2007, de 3 de julho, considera o Encarregado de Educação como o sujeito que tiver menores à sua guarda nas seguintes condições: a) Pelo exercício do poder paternal; b) Por decisão judicial; c) Pelo exercício de funções executivas na direção de instituições que tenham menores, a qualquer título, à sua responsabilidade; d) Por decisão, devidamente comprovada, por parte de qualquer das entidades referidas nas alíneas anteriores.
} 
Em contexto escolar extra-aula, e então num contexto mais informal de atuação, tipos de poder como "o poder normativo", "o poder coercitivo", digamos mesmo "o poder disciplinar" são reforçados. Aqui, os alunos são sujeitos a "muita pressão [...]. Querem espaço e ele [o diretor] não os deixa circular pela escola. São as ordens lá de cima [do Diretor]. Os alunos dizem, caramba, isto é uma escola, não é uma prisão. Os alunos têm razão" (Entrevista - assistente operacional 2). Neste contexto informal mas extremamente normativo e de regulação de todos os comportamentos, emergem correlações de forças que levam os alunos "a saltar o muro da escola", até porque,"eram alunos que tinham estado no professor (nome do diretor) para este os deixar sair da escola e ele não os deixou” (Entrevista - assistente operacional 3). E, "O meu colega foi lá em cima comunicar e a resposta que teve foi: Saltou o muro da escola, fugiu, quero lá saber. [...]. A preocupação do diretor é o portão. Por ali ele não quer que eles saiam" (Entrevista - assistente operacional 3).

Os alunos admitem que nos intervalos, por vezes, andam "à porrada [...]. Umas vezes é na brincadeira, outras vezes é a sério” (Entrevista - aluna 7). Torna-se "normal": "Riscar as paredes com giz ou corrector e partir vidros com a bola" (Entrevista - aluno 1) ou "Fumar nos intervalos. Partir vidros e escrever nas paredes" (Entrevista - aluno 3) ou, ainda, "tatuarem-se com o x - ato (cortante)" (Entrevista - aluno 5) e "Sair da escola [...] pelas grades" (Entrevista - aluno 2). Tudo isto são formas que os alunos encontram para mostrar sua capacidade para alterar a ordem institucional vigente, são afirmações do poder de contestação e resistência ao poder instituído na escola e que se manifestam "[...] na maneira como falam, mesmo a comer deitam para o chão...não são todos não é" (Entrevista - assistente operacional 2).

Neste registro, e como último reduto disciplinar, o diretor entende que os alunos devem permanecer, no intervalo, sentados à porta de seu gabinete. $\mathrm{Na}$ prática, "todos já perceberam que se a escola tem um Diretor, é para o Diretor mandar" (coordenador de departamento, em reunião). Ficar sentados à porta do gabinete do diretor, "Não é muito simpático. Poderá ser uma vergonha [...]", apesar de ser "uma solução rápida e descartável" (Entrevista - mãe 2). A adjunta do diretor "Não [vê nisto] utilidade pedagógica" e prefere "não comentar" o poder disciplinar que o diretor exerce sobre os alunos (conversa informal).

Este "poder disciplinar" é entendido pelos discentes como "um castigo porque nos intervalos estamos a olhar uns para os outros. Estamos a olhar as pessoas a passar" (Entrevista - aluno 3) e "Não acontece nada. Só nos tiram o intervalo" (Entrevista - aluno 11), "[...] não podem falar com os colegas e é isso" (Entrevista - aluno 2) e estão "lá sentados à espera que passe o tempo [o intervalo] a jogar nos telemóveis" (Entrevista - aluna 4) e à espera de "assinar num papel, que está [...] junto à empregada na entrada” (Entrevista - aluno 3). 
Conquanto assim seja, os alunos reconhecem, em maior ou menor grau, o "poder de cargo" ou "poder de especialista" que emana da posição oficial do diretor. Dizem que quem manda na escola "é o Diretor da escola. Talvez alguns alunos queiram mandar mas não conseguem" (Entrevista - aluna 10). Relatam ainda os alunos que as características pessoais, afetivas, temperamentais e de personalidade do diretor são indutoras de um fraco "poder pessoal". O Diretor "tem uma má relação [com os alunos]. Ninguém gosta dele. Está sempre a berrar. Que vá berrar com os filhos dele. Não consegue ter uma conversa calma. Começa logo a berrar. Às vezes até parece que nos come com os olhos" (Entrevista - aluna 4).

Não reconhecendo o "poder pessoal" do diretor, os alunos aproveitam suas próprias capacidades para contornar também o "poder de incerteza" do mesmo. Assim, percebem as debilidades e incertezas organizacionais e fazem valer seu "poder de executores" nestes termos: apesar de ter sido retirada a autorização de sair da escola, "eu saio na mesma. É fácil. Os alunos que querem sair da escola escrevem num papel: Autorizo o meu educando a sair à hora de almoço - e ninguém dá por nada" (Entrevista - aluno 5). E,

Assinávamos no fim do intervalo o papel e vínhamos embora. Outras vezes nem íamos assinar e não queriam saber. Assinei dois dias e não assinei mais. Nunca mais assinei e nunca ninguém me perguntou nada. O papel também era uma folha em branco (Entrevista - aluno 3); Eu risquei [as paredes da escola] e tinha que limpar, [...] mas o professor (nome do Diretor) esqueceu-se. Andou atrás de mim, foi a muitas turmas à minha procura mas foi sempre à turma errada. Um dia, finalmente, veio a esta turma para perguntar por mim. Entrou na sala de disse: É desta turma, a aluna (nome da aluna)? Sim, sou eu. Então, no intervalo passa pelo gabinete. Eu fui lá, como ele pediu. Como não estava, nunca mais lá fui. Depois disso, soube que já andou à minha procura. Mas como vai às turmas erradas nunca me encontra. (Entrevista - aluna 4).

Um outro aspeto que merece nossa análise centra-se nas explicações avançadas pelos atores como forma de justificação dos problemas existentes. Verifica-se uma forte tendência a atribuir o insucesso e a indisciplina a causas externas à escola, nomeadamente aos contextos de socialização familiar. As explicações avançadas como forma de justificação dos problemas relacionam-se com:

[...] a mentalidade das famílias que, ainda hoje, não estimulam os seus filhos a procurarem novos horizontes e expectativas através do ensino, da formação profissional e da cultura, razão pela qual a precipitada fuga à escolaridade, a precoce entrada no mundo do trabalho mal remunerado ou a inação e a marginalidade [...]. (PROJETO EDUCATIVO, 2007/ 2010, p. 2).

Esta referência à família como núcleo gerador de problemas é feita por muitos professores, encarregados de educação, assistentes operacionais e mesmo 
alunos com sucesso escolar em todas as disciplinas. As próprias relações de poder em contexto familiar, segundo os alunos da amostra, podem ser até indutoras de relações conflituosas em contexto escolar, visto que "os alunos [...] mandam nos pais. Fazem o que querem dos pais. [...] vir os pais à escola não interessa para nada" (Entrevista - aluno 3). Para além disso, os encarregados de educação vêm "poucas vezes à escola [porque] têm que trabalhar. [...] e quando é convocado [...] nunca é para dizer bem de mim” (Entrevista - aluno 2). E, "Às vezes a diretora de turma faz mais queixas do que acontece" (Entrevista aluno 11).

Em contextos familiares problemáticos, a escola adquire centralidade na educação das gerações jovens, tendo em conta que os pais abdicam de sua função educativa, "deixando os alunos à mercê da escola dando a responsabilidade total aos professores como sendo estes os protagonistas para resolver todos os problemas que a sociedade enfrenta, desperdiçando o seu tempo de ensinar" (Entrevista - professora 6). E muitos problemas derivam "do fato de a maior parte dos alunos estar entregue a si mesmo, de não terem quem sirva de referência e quem controle as suas atitudes" (Entrevista - professora 7). Veja-se que:

[...] a Vila [...] é uma zona que tem grande desemprego, o que tem influenciado a desestruturação crescente da família. Existe um grande número de agregados familiares com o Rendimento de Inserção Social. [...] as relações parentais são tão instáveis, que os alunos não se conseguem concentrar nas aulas. [...] os que trabalham não têm horário certo e os filhos estão sozinhos até às tantas. Podem ver televisão, Internet à vontade sem nenhuma orientação. (Entrevista - professor 4).

Dentre o rol das explicações avançadas como forma de justificação, dos problemas que ocorrem na escola refere-se, ainda, que "os resultados pouco satisfatórios devem-se a lacunas graves quanto a competências básicas para o nível de ensino em questão", isto apesar de a escola ter possibilitado "todos os apoios escolares, que os alunos não aproveitaram" (ata do conselho de turma). Assim se vê como a escola Lua-Sol se redime de seu papel educativo. Raramente são evocados os problemas estruturais da própria escola, no entanto, os alunos com dificuldades, "no $3^{\circ}$ ciclo, neste nível de ensino estão nas aulas sem fazer nada", porque se encontram afastados dos referenciais escolares, em resultado de "não serem ajudados no $1^{\circ}$ ciclo, pelos professores ou pelos pais, [e] nunca mais conseguem superar" (Entrevista - professor 4). Então, parte destes problemas têm que ser imputados ao modo como é coordenado e orientado o funcionamento das várias estruturas escolares. Pois:

[...] o tempo dos intervalos [que] não chega para os alunos descarregarem as energias, [porque é neste período], [...] que vão à papelaria e ao bar, sobrando pouco tempo para brincarem e conversarem com os colegas. [Naturalmente], 
se não podem conversar fora das aulas, é nas aulas que eles, muitas vezes, combinam até uma festa de anos. (Entrevista - professor 5).

\section{Síntese}

Nesta análise sobre a problemática das relações de poder entre os vários atores educativos, impôs-se focalizar o "olhar" sobre as configurações estruturais que a escola adquire quando atravessada por relações de poder. A principal imagem que se pode captar é a de um espectro organizacional burocrático, em que todas as regras e normas escritas são definidas a priori, no topo da hierarquia que, no caso em estudo, são muitas vezes subvertidas e mesmo antecipadas pelo "poder autoritativo" exercido pelos professores e pelo "poder disciplinar" exercido pelo Diretor. Assim, os atores organizacionais não deixam de aproveitar as margens de ambiguidade para consciente ou inconscientemente incorrer em "infidelidades normativas", de maior ou menor importância, mas com uma ausência significativa de imputs para uma fase de discussão política, de regateio e negociação de outras soluções possíveis.

Então, se é certo que momentos e espaços há em que os atores escolares produzem relações de poder instituintes que contrariam o poder instituído (ROCHA, 2007), não deixa de ser menos certo que as relações de poder entre os vários atores escolares possuem um cariz predominantemente normativo/prescritivo, isto é, configuram a prevalência do "poder autoritativo", pese embora as práticas de "resistência simbólica" por parte dos alunos, ou mesmo seus "atos de rebelião".

Podemos dizer com toda a certeza que a circulação do poder ou dos poderes no interior da escola como organização, realiza-se no plano da ação, no sentido "descendente ou hierárquico" exercido fundamentalmente pelos professores e pelo Diretor que controlam os alunos, fazendo cumprir suas ordens. A circulação do poder "ascendente", exercido pelos alunos, e a durabilidade de regras informais só se concretizam pontualmente na escola, sendo estas constantemente derrubadas pelo peso das regras formais e não formais.

Desta feita, o "poder" é visto e consolidado na escola sob a forma de "poder normativo" ou como "poder autoritativo" e não o é, como seria desejável, integrado num "modelo mais relacional" com o qual se consiga diluir uma concepção de "poder" que remete para a prevalência em exclusivo de formas culturais e ideológicas tendentes à coerção de uns atores sobre outros. Em suma, "nesta escola funciona pelo medo. Não concordo com esta dominação" (Entrevista professor 4). E, mesmo assim, é num contexto educativo tão desigual que os gestores e professores manifestam um certo saudosismo pela "autoridade perdida", digamos pelo autoritarismo. 
Defendemos que na escola o que está em "jogo" no momento presente é a capacidade que o paradigma educacional possui de fornecer às gerações jovens a capacidade de pensar e atuar em liberdade, o que, do ponto de vista emancipatório, fundamenta-se "numa teoria da ética baseada nos princípios da democracia, da solidariedade e da esperança” (GIROUX, 1993, p. 128-129). Então, "a escola deve ser um lugar de interpretação do mundo [...], não só introduzindo os alunos à prática de uma certa solidariedade como também transmitindo-lhe um quadro problematizado de referências comuns", capaz de transformar os jovens que a frequentam num devir de esperança e não num problema (SANTOS, 1993, p. 65).

Trata-se, nas palavras de Paulo Freire (1977, p. 47), de consolidar experiências indutoras de possibilidade que constituem a "chave das transformações sociais" e que funcionam para os alunos como uma "bússola" que lhes permite orientar-se num mundo em permanente transformação. Pese embora também assim pensarmos, estamos conscientes da complexidade dos problemas a que a escola tem que dar resposta, num registro pautado por um equilíbrio em desequilíbrio permanente entre os vários atores escolares em presença e entre seus mundos interorganizacionais. De qualquer forma, as finalidades da escola pública como organização democrática, inscritas na Constituição da República Portuguesa (1976) e na Lei de Bases do Sistema Educativo (1986), só se efetivarão a partir de uma escola que mobilize relações de poder mais comunicativas, nas quais a firmeza, mas também a tolerância capacite os vários atores escolares a pilotar, a surfar e a gerir suas vivências escolares num registro menos tenso e crispado. É neste paradigma de relações de poder mais simétricas que a escola pode evitar que o tempo e as vivências escolares de seus atores se transformem num tempo e em vivências vazias de sentido.

\section{Referências}

AFONSO, A. J. Relações de Poder no Quotidiano da Escola e da Sala de Aula. Elementos para uma Análise Sociológica e Organizacional. Cadernos de Ciências Sociais, n. 10/11, p. 133-155, 1991 a.

AFONSO, A. J. O poder de avaliar na génese de uma sociologia da avaliação. In: AFONSO, A. J. (Org.). O Professor, n. 22, p. 41-50, 1991 b.

APPLE, M. Educação e Poder. Porto: Porto Editora, 2001.

BOURDIEU, P.; PASSERON, J. C. A Reprodução: elementos para uma teoria do sistema de ensino. Lisboa: Veja, 1975.

BOURDIEU, P.; CHAMPAGNE, P. Os excluídos do interior. In: BOURDIEU, P. (Org.). A miséria do mundo. Petrópolis: Editora Vozes, 1999. p. 481-486. 
CERTEAU, M. de. A invenção do quotidiano. Artes de fazer. Petrópolis: Editora Vozes, 1998.

CROZIER, M. O fenómeno burocrático. Brasília: Universidade de Brasília: ASA Norte, 1981.

CROZIER, M.; FRIEDBERG, E. L'acteur et le système. Les Contraintes de l'Action Collective. Paris: Éditions du Seuil, 1977.

DELAMONT, S. Interacção na sala de aula. Lisboa: Livros Horizonte, 1987.

DURKHEIM, E. Sociologia, educação e moral. Porto: RÉS-Editora, 1984.

ETZIONI, A. Análise comparativa de organizações complexas. Sobre o poder, o engajamento e seus correlatos. São Paulo: Zahar Editores, 1974.

FERNANDES, A. As relações de poder na escola pública - dos normativos aos discursos organizacionais. 2011. 281 f. Dissertação (Mestrado em Educação Administração Educacional) - Universidade do Minho, Braga, 2011.

FORMOSINHO, J. As Bases do poder do professor. Coimbra: Faculdade de Letras da Universidade de Coimbra, 1980.

FOUCAULT, M. Vigiar e punir. Petrópolis: Editora Vozes, 2009.

FREIRE, P. A mensagem de Paulo Freire: teoria e Prática da Liberdade. Textos de Paulo Freire selecionados pelo INODEP. Porto: Editora Nova Crítica, 1977.

FREIRE, P. Pedagogia da autonomia. Saberes necessários à Prática Educativa. São Paulo: Paz e Terra, 1986.

GIROUX, H. Teoria crítica e resistência em educação. Para Além das Teorias da Reprodução. Petrópolis: Vozes, 1986.

GIROUX, H. La Escuela y la lucha por la ciudadania. Madrid: Siglo Veintiuno, 1993.

GIROUX, H. Professores como intelectuais: rumo a uma pedagogia crítica da aprendizagem. Porto Alegre: Artes Médicas, 2001.

LIMA, L. C. A escola como organização e a participação na organização escolar. Braga: Universidade do Minho, 1998.

LIMA, L. C. A Escola como organização educativa. Uma Abordagem Sociológica. São Paulo: Cortez, 2003.

PARSONS, T. Power and the Social System. In: LUKES, S. (Edit.). Power. Oxford: Blackwell Publishers, 1986. p. 94-143.

PORTUGAL. Decreto-Lei n. ${ }^{\circ}$ 3/2008, de 18 de janeiro de 2008. Assembleia da República. Primeira alteração à Lei n. ${ }^{\circ}$ 30/2002, de 20 de Dezembro, que aprova o Estatuto do Aluno dos Ensinos Básico e Secundário. Diário da República, Lisboa, 18 jan. 2008a.

PORTUGAL. Decreto-Lei n. ${ }^{\circ}$ 75/2008 de 22 de abril de 2008. Regime de Autonomia Administração e Gestão Regime de Autonomia, Administração e Gestão dos Estabelecimentos Públicos da Educação Pré-Escolar e dos Ensinos Básico e Secundário. Diário da República, Lisboa, 22 abr. 2008b. 
PORTUGAL. Decreto-Lei Lei n. ${ }^{\circ}$ 51/2012 de 5 de setembro de 2012. Assembleia da República. Aprova o Estatuto do Aluno e Ética Escolar, que estabelece os direitos e os deveres do aluno dos ensinos básico e secundário e o compromisso dos pais ou encarregados de educação e dos restantes membros da comunidade educativa na sua educação e formação, revogando a Lei n. ${ }^{\circ}$ 30/2002, de 20 de dezembro. Diário da República, Lisboa, 05 set. 2012. PORTUGAL. Decreto-Lei no 46/86 de 14 de outubro de 1986. Lei de Bases do Sistema Educativo. Diário da República, Lisboa, 14 out. 1986.

PORTUGAL. Constituição da Republica Portuguesa (1976). Lei do Tribunal Constitucional. Constituição da República Portuguesa de 02 de abril de 1976. Lisboa, Imprensa NacionalCasa da Moeda. Revista pelas Leis Constitucionais, Coimbra, 02 abr. 1976.

RIBEIRO, L. C.; BREGUNCI, MG. C. O papel de autoridade do professor: as bases do poder social como foco de análise da interação em sala de aula. Revista Brasileira de Estudos Pedagógicos, Brasília, v. 149, n. 65, p. 70-78, 1984.

ROCHA, M. C. J. Educação, género e poder: uma análise política, sociológica e organizacional. Braga: Universidade do Minho, Centro de Investigação em Educação, 2007.

SANTOS, L. F. O caso da educação desfundamentada. Revista Portuguesa de Educação, Braga, n. 6, p. 53-70, 1993.

SEDANO, M.; PEREZ, M. Modelos de organización escolar. Madrid: Editorial Cincel S. A., 1989.

WEBER, M. Economia y sociedad: esbozo de Sociología Comprensiva. México: Fondo de Cultura Económica, 1993.

\section{Outros documentos referenciados}

Dossiê / arquivo das ocorrências registadas pelos professores, em contexto de sala de aula $(2009$ - 2010).

Jornal Público, 13 de fevereiro de 2013.

Livro de ponto do GOPI (2009 - 2010).

Projeto Educativo (2007 - 2010).

Regulamento Interno (2010).

Regulamento Interno (2012).

Relatório do GOPI (2010).

Relatório da avaliação interna do Agrupamento de Escolas (2010).

Relatório da avaliação externa do Agrupamento de Escolas, elaborado pela Inspeção-Geral da Educação (2009-2010).

Várias Atas.

Recebido em 01/03/2013

Versão final recebida em 10/05/2013

Aceito em 16/10/2013 